\title{
Ixodids in wild animals of the mountainous plateau Region of Santa Catarina State, Brazil
}

\section{Ixodídeos em animais silvestres na Região do Planalto Serrano, Estado de Santa Catarina, Brasil}

\author{
Marcia Sangaletti Lavina ${ }^{1 *}$; Antonio Pereira de Souza ${ }^{2}$; \\ Amélia Aparecida Sartor ${ }^{3}$; Anderson Barbosa de Moura ${ }^{3}$
}

\begin{abstract}
Knowledge of ixodids (hard ticks), as of well as their ability to transmit pathogens to their hosts, and in some cases to humans, is significantly important for the establishment of epidemiological public health programs and surveillance. With the purpose of identifying ixodids from wild mammals in the mountainous plateau of Santa Catarina, we examined ticks collected or received in the Laboratory of Parasitology and Parasitic Diseases of the Centre of Agroveterinary Sciences (CAV/UDESC) from 2001 to 2011. The ixodids were collected from wild animals that were subjected to the screening process of the Veterinary Clinic Hospital (HCV) of CAV and from dead animals found on state highways. Using specific dichotomous keys, we identified Amblyomma aureolatum collected from Pseudalopex gymnocercus, Lycalopex gymnocercus, Leoparduspardalis, Cerdocyon thous, Leopardus tigrinus, Puma concolor, and Bufo sp.; A. dubitatum collected from Hydrochoerus hydrochoeris; A. rotundatum from Puma concolor and Bohtrops sp.; A. ovale from Bufo sp.; and Rhipicephalus microplus from Mazama gouazoubira. A specimen of $A$. longirostre was identified in an urban area house at the municipality of Lages. A. rotundatum that was collected from Bohtrops sp. and Puma concolor, and A. longirostre that was found in the environment, are reported for the first time in the state of Santa Catarina, Brazil.
\end{abstract}

Key words: Amblyomma spp., wild animals, ixodids, Santa Catarina

\section{Resumo}

O conhecimento da fauna de ixodídeos, bem como a potencialidade como transmissores de patógenos aos seus hospedeiros e em alguns casos aos humanos, é de grande importância para o estabelecimento de programas de saúde pública e vigilância epidemiológica. Com o objetivo de identificar ixodídeos de mamíferos silvestres no Planalto Serrano de Santa Catarina foram examinados carrapatos, coletados ou recebidos no Laboratório de Parasitologia e Doenças Parasitárias do Centro de Ciências Agroveterinárias - CAV/UDESC no período 2001 a 2011. Os ixodídeos eram provenientes de animais silvestres que passaram pelo processo de triagem do Hospital de Clínicas Veterinárias (HCV) do $\mathrm{CAV}$ e de animais encontrados mortos em rodovias do Estado. De acordo com as chaves dicotômicas específicas identificou-se Amblyomma aureolatum coletados em Pseudalopex gymnocercus, Lycalopex gymnocercus, Leopardus pardalis, Cerdocyon thous, Leopardus tigrinus, Puma concolor e Bufo sp.; A. dubitatum em Hydrochoerus hydrochoeris; A. rotundatum em Puma concolor e Bohtrops sp.; A. ovale

\footnotetext{
1 Discente do Curso de Doutorado do Programa de Pós-Graduação em Ciência Animal, Centro de Ciências Agroveterinárias, CAV, Universidade do Estado de Santa Catarina, UDESC, Lages, SC, Brasil. E-mail: marciavetcav@yahoo.com.br

2 Prof. Visitante Sênior, Instituto Federal Catarinense, IFC, Campus de Araquari, Bolsista PVNS/CAPES, Brasil. E-mail: antonio. souza@ifc-araquari.edu.br

3 Profs. Drs., Dept ${ }^{\circ}$ de Medicina Veterinária, Centro de Ciências Agroveterinárias, CAV, UDESC, Lages, SC, Brasil. E-mail: amelia.sartor@udesc.br; anderson.moura@udesc.br

* Author for correspondence
} 
em Bufo sp.; e Rhipicephalus microplus em Mazama gouazoubira. Foi identificado um exemplar de A. longirostre que se encontrava em uma residência da área urbana do município de Lages. As espécies A. rotundatum em Bohtrops sp. e em Puma concolor; e A. longirostre, encontrada no ambiente, foram relatadas pela primeira vez no estado de Santa Catarina, Brasil.

Palavras-chave: Amblyomma spp., animais silvestres, ixodídeos, Santa Catarina

\section{Introduction}

During the process of attachment and feeding, ticks are responsible for extensive damage to the host, including mechanical damage, trauma, despoiling, and toxic action. These arthropods are also responsible for transmitting pathogenic microorganisms through their saliva, which penetrates the host skin; this makes the ixodids the second vector group that most frequently transmits pathogens to humans, surpassed only by the Culicidae group of mosquitoes (MASSARD; FONSECA, 2004).

In this context, faunal surveys of ticks become an essential tool in recognizing and determining the occurrence of ticks, especially where there is interaction between wildlife and pets. According to Williams et al. (2002), controlling interactions between domestic and wild environments is the first step to estimate the risk of disease outbreaks.

According to Figueiredo et al. (2010), Brazil is one of the countries with the greatest biodiversity in the world, and to manage this living heritage, relevant strategies, plans, and programs must be established to ensure the sustainable use of available natural resources. The study of parasitic diseases and parasite-host interactions of wild animals, captive or free-living, is a key step in supporting conservation and preservation programs (CATÃO-DIAS, 2003). Tick species from domestic animals are the most studied, while species that parasitize wildlife are still poorly known, particularly in relation to taxonomy, biology, ecology, geographical distribution, their usual hosts, and their vector capacity as bioagents (BARROS-BATTESTI et al., 2006).

\section{Materials and Methods}

The mountainous plateau or sierra of Santa Catarina is a state region that includes the mesoregions of the west of Santa Catarina, the mountains, and part of the north of Santa Catarina. Many of the cities in the mountainous plateau are located over a thousand meters above sea level, and as a result during the winter months average temperatures do not exceed $10^{\circ} \mathrm{C}$, with the presence of frost and the possibility of snow. The mountainous plateau region of Santa Catarina presents varying climatic characteristics, including harsh winters, mild springs and summers, and autumn with alternating temperatures between day and night periods (BACK et al., 2013).

According to the Köppen-Geiger classification, the climate of Santa Catarina receives the Cfa and $\mathrm{Cfb}$ designations. The first is subtropical with hot summers in which the temperature of the warmest month is higher than $22^{\circ} \mathrm{C}$, and the second is the subtropical climate with mild summers. The Cfa climate belongs to the lower regions, while the $\mathrm{Cfb}$ occurs in areas of higher altitudes such as the mountainous plateau (MONTEIRO, 2001).

The vegetation of the mountainous plateau region is characterized by Araucaria forest comprising associations and groups of species with various names, including pine forest, pinewoods, pine zone, and Araucaria woodlands. The vegetation of this region also includes natural pasture areas composed of shrubs and grass, which are aimed at animal ranching.

In the period from 2001 to 2011 , adult hard ticks were collected from ten different species of wild animals that underwent the screening process at the Veterinary Clinic Hospital (HCV) at the CAV and/ 
or were collected from dead animals on highways of the plateau region. The ixodids attached to wild mammals were found in the animals' skin by inspection and manually removed; subsequently, they were stored in bottles containing $70 \%$ alcohol identified with labels containing information about the host, place, and date of collection. The identification of adult instars was carried out under a stereomicroscope, according to the dichotomous key of Barros-Battesti et al. (2006).

This study was approved by the Ethics Committee of the institution (UDESC/CAV) where it was conducted.

\section{Results and Discussion}

In all, 173 adult ticks from five different species were identified, and these are presented, according to the host species, in Table 1. Among the tickhost associations found, it is worth mentioning $A$. rotundatum that was collected from Bohtrops sp., and the accidental parasitism of Puma concolor. In regard to $A$. longirostre found in the environment, this is the first report of this species in the Santa Catarina State, Brazil.

Table 1. Number of adult ixodid parasites of wild animals collected and identified in some municipalities of the mountainous plateau of Santa Catarina State.

\begin{tabular}{lccc}
\hline \multicolumn{1}{c}{ Host } & Location & $\begin{array}{c}\text { Number of collected } \\
\text { Ectoparasites }\end{array}$ & Identified Ectoparasites \\
\hline Leopardus tigrinus & Lages & 01 & Amblyomma aureolatum \\
Hydrochoerus hydrochoeris & São José do Cerrito & 94 & Amblyomma dubitatum \\
Bufo sp. & Lages & 02 & Amblyomma aureolatum \\
Bufo sp. & Lages & 02 & Amblyomma ovale \\
Puma concolor & Curitibanos & 18 & Amblyomma aureolatum \\
Puma concolor & Lages & 10 & Amblyomma aureolatum \\
Puma concolor & Campo Belo do Sul & 01 & Amblyomma rotundatum \\
Cerdocyon thous & Bom Retiro & 16 & Amblyomma aureolatum \\
Cerdocyon thous & Lages & 05 & Amblyomma aureolatum \\
Mazama gouazoubira & Lages & 13 & Rhipicephalus microplus \\
Pseudalopex gymnocercus & Lages & 08 & Rhipicephalus microplus \\
Lycalopex gymnocercus & Lages & 01 & Amblyomma aureolatum \\
Leopardus pardalis & Lages & 01 & Amblyomma aureolatum \\
Bohtrops sp. & Lages & 01 & Amblyomma rotundatum \\
\hline Total & & 173 & \\
\hline
\end{tabular}

The species identified were as follows: $A$. aureolatum collected from ocelot (Leopardus pardalis), toad (Bufo sp.), pampas fox (Lycalopex gymnocercus), crab-eating fox (Cerdocyon thous), oncilla(Leopardus tigrinus), puma (Puma concolor), and pampas fox (Pseudalopex gymnocercus); $A$. rotundatum from snake (Bohtrops sp.) and puma (Puma concolor); R. microplus from pampas fox and gray brocket deer (Mazama gouazoubira); A. ovale from toad; and A. dubitatum from capybara (Hydrochoerus hydrochoeris).

According to Barros-Battesti et al. (2006), A. aureolatum and $A$. ovale are closely related species that in the adult phase are parasites of carnivores, the later species also reaching to other species such as procyonids and mustelids (LABRUNA et al., 2005). In Santa Catarina State, we identified A. aureolatumin wild felines and canines; and 
its presence in oncilla confirms the occurrence of ixodids in wild felines of Santa Catarina. Martins et al. (2010) also recorded parasitism by this species in margays (Leopardus wiedii), in the metropolitan region of Porto Alegre, Rio Grande do Sul State.

Specimens of $A$. aureolatum found in the crabeating fox were also reported by Rodrigues and Daemon (2004), who observed the presence of the species in Cerdocyon thous coming from the "Zona da Mata" of Minas Gerais State. According to Aragão and Fonseca (1961), the species is regularly found in the wild animals of dog-inhabited areas, especially wild canines and felines.

In the northern region of Santa Catarina the species A. aureolatum and A. ovale were reported in monkeys in the cities of Indaial, Blumenau, Garuva, and Jaraguá do Sul (LAVINA et al., 2011), climate region $\mathrm{Cfa}$, which indicates that this species is well adapted to the Santa Catarina climate, with its variations in $\mathrm{Cfa}$ or $\mathrm{Cfb}$.

The infestation of frogs by adult ticks of $A$. aureolatum and $A$. ovale is considered an extremely unusual parasitism, primarily because amphibians are not the preferred hosts of these species. Secondly, because in this study, A. ovale has not been reported with expression in carnivores, the hosts might have contributed to an accidental parasitism of $A$. ovale in $B u f o$ spp. Unusual parasitism of frogs has been reported by other authors, such as Sinkoc and Brum (1997), who recorded the presence of A. fuscum and A. humerale in Bufo arenalis in São Paulo State. At the time, the account given by those authors featured a new host and a new geographic location for both species. Guglielmone et al. (2003) studied $A$. aureolatum and $A$. ovale and reported the presence of a male $A$. ovale in a toad. Luz and Faccini (2013), in a review of parasitism of frogs by ticks in Brazil, described $A$. dissimile and $A$. rotundatum as the most common species in these animals, despite the large number of species of ticks. The authors also reported the presence of A. fuscum, A. goeldii, A. humerale, and $A$. sculptum in frogs, in particular those belonging to the genus Rhinella; and since A. sculptum is considered exclusively parasitic in warm-blooded animals such as mammals and birds, the authors consider this case to be a totally accidental parasitism. Robinson (1926) had already reported Bufo marinus as a host for A. sculptum (a species of the $A$. cajennense complex), A. dissimile, and A.goeldii; and Bufo sp. as a host of $A$. goeldii and $A$. rotundatum.

In Rhinella schneideri in the state of Paraná, Antonucci et al. (2011) recorded the presence of $A$. rotundatum, and Ahid et al. (2009) made the first report of the species parasitizing frogs in Mossoró, Rio Grande do Norte State.

The species $A$. rotundatum was found parasitizing snake and puma in Florianópolis, Santa Catarina State, by Aragão (1936), but that author did not mention the species of the host. The parasitism found in puma can be considered an accidental parasitism as amphibians and reptiles are usual hosts for this species of hard tick. A female $A$. rotundatum was identified on a snake (Bothrops sp.), confirming the work of Brum and Costa (2003) who identified A. rotundatum in the crossed pit viper (Bothrops alternatus) in the south region of the municipality of Pelotas, Brazil.

Labruna etal.(2002) also identified A.rotundatum in Bothrops moojeni (Brazilian lance head) and Boa constrictor ("jibóia"), and Figueiredo et al. (2010) found adults of the same species in Boa constrictor and Iguana.

This current record of $R$. microplus parasitizing Pseudalopex gymnocercus and Mazama gouazoubira reinforces previous findings in the literature that this tick species can parasitize other host species that, even if temporarily, share the same cattle infested pasture (LABRUNA et al., 2005). Under these conditions it has been described in other animals such as the marsh deer (Blastocerus dichotomus) (SZABÓ et al., 2003) and the white lipped peccary (ITO et al., 1998). The participation of these hosts in maintaining this tick species in 
the environment appears to be more important than might be expected, to the point that Graham and Hourrigan (1977) reported that in the United States, $R$. microplus was considered eradicated in 1943 through the chemical control and management of the white-tailed deer population (Odocoileus virginianus). In 1952, in Puerto Rico, through chemical control and elimination of the deer population on the island, as well as in New Guinea, R. microplus was eradicated (PEREIRA, 2008).

Present from north to south in South America, A. dubitatum has been reported in Brazil in states in the southeast, south, and midwest (CAMARGONEVES, 2004). It was the only species found parasitizing capybaras, but the number of samples collected for this host was only three. In Lages, Quadros et al. (2013) found adults of A. sculptum (a species belonging to the $A$. cajennense complex) and nymphs of $A$. dubitatum in capybaras run over on a highway. According to Famadas et al. (1997), although the capybaras are considered primary hosts for all parasitic stages (larva, nymph, and adult) of the $A$. dubitatum tick, the larva and nymph stages have lower parasitic specificity and can feed on different host species, including humans.

The observation of $A$. longirostre in our study in a house in the Lages municipality urban area may be explained by the fact that the species in its immature stage parasitizes birds, especially wild birds, and so can be dispersed by them to other environments where mammals belonging to the order Rodentia are the main hosts for the adult stage of this species (BARROS-BATTESTI et al., 2006).

Teixeira et al. (2008), in a study of wild birds' ticks of the Sorocaba Zoo in São Paulo State, found A. longirostre in the ruby-crowned tanager (Tachyphonus coronatus), in the red-legged seriema (Cariama cristata), and in the peacock (Pavo cristatus). Labruna et al. (2002) found A. longirostre in Brazilian porcupine (Coendou prehensilis), and Silveira et al. (2008) found A. longirostre in the black urchin (Chaetomys subspinosus). In Brazil, the species is well established in the states of Parana, Santa Catarina, Rio Grande do Sul, São Paulo, Rio de Janeiro, Minas Gerais, Goiânia, Pernambuco, Acre, Amazonas, Pará, and Rondônia (ARZUA et al., 2005; GUIMARÃES et al., 2001).

\section{Conclusions}

To our knowledge, this is the first report of $A$. rotundatum in Bohtrops sp. in Santa Catarina and the first record of $A$. longirostre in the state. We believe that the findings of our study contribute to knowledge of the parasitic fauna of wild animals, establishing new areas of occurrence and clarifying the geographical distribution of ectoparasites, especially in poorly studied places such as the state of Santa Catarina.

\section{Acknowledgements}

The authors express their thanks to CAPES (Higher Education Personnel Improvement Coordination) for the financial support for the publication of this article.

\section{References}

AHID, S. M. M.; FONSECA, Z. A. A. S.; FERREIRA, C. G. T.; MARTINS, T. F.; OLIVEIRA, M. F. de. Parasitismo de Amblyomma rotundatum (Koch) (Acari: Ixodidae) em Bufo marinus (Linnaeus) (Anura: Bufonidae), em Mossoró, Rio Grande do Norte, Brasil. Revista Brasileira de Zoociências, Juiz de Fora, v. 11, n. 2, p. 153-156, 2009.

ANTONUCCI, A. M.; ODA, F. H.; SIGNORELLI, L.; SANTANA, N. F.; MENDES, M. C. Parasitismo de Amblyomma rotundatum (Koch, 1844) (Acari: Ixodidae) em Rhinella schneideri (Werner, 1894) (Anura: Bufonidae) no Estado do Paraná, Brasil. Natureza on line, Santa Teresa, v. 9, n. 3, p. 103-105, 2011.

ARAGÃO, H. B. Ixodidas brasileiros e de alguns países limítrofes. Memórias do Instituto Oswaldo Cruz, Rio de Janeiro, v. 31, n. 4, p. 759-843, 1936. 
ARAGÃO, H. B.; FONSECA, F. Notas de ixodologia: IX, o complexo ovale do gênero Amblyomma. Memórias do Instituto Oswaldo Cruz, Rio de Janeiro, v. 59, n. 2, p. 131-148, jul. 1961.

ARZUA, M.; ONOFRIO, V. C.; BARROS-BATTESTI, D. M. Catalogue of the tick collection (Acari: Ixodida) of the Museu de História Natural Capão da Imbuia, Curitiba, Paraná, Brazil. Revista Brasileira de Zoologia, Curitiba, v. 22, n. 3, p. 623-632, 2005.

BACK, A. J.; BRUNA, E. D.; FELIPETTO, J. Tendências nos índices climáticos e agroclimáticos aplicados à videira no Planalto Serrano de Santa Catarina. Revista Brasileira de Climatologia, Curitiba,v. 13, n. 9, p. 137-148, jul./dez. 2013. Disponível em: <http://ojs.c3sl.ufpr.br/ojs/index. php/revistaabclima/article/viewFile/33720/22586>. Acesso em: 12 mar. 2015.

BARROS-BATTESTI, D. M.; ARZUA, M.; BECHARA, G. H. Carrapatos de importância médico-veterinária da Região Neotropical: um guia ilustrado para identificação de espécies. São Paulo: Vox/ICTTD-3/Butantan, 2006. $223 \mathrm{p}$.

BRUM, J. G. W.; COSTA, P. R. P. Confirmação da ocorrência da espécie Amblyomma rotundatum Koch, 1844 (Acari: Ixodidae) no Rio Grande do Sul. Arquivos do Instituto Biológico, São Paulo, v. 70, n. 1, p. 105-106, jan./mar. 2003.

CAMARGO-NEVES, V. L. F. Manual de vigilância acarológica. São Paulo: Secretaria de Estado da Saúde/ Superintendência de Controle de Endemias, 2004. 62 p.

CATÃO-DIAS, J. L. Doenças e seus impactos sobre a biodiversidade. Ciência e Cultura, Campinas, v. 55, n. 3, p. 32-34, 2003.

FAMADAS, K.; LEMOS, E. R. S.; COURA, J. R.; SERRA-FREIRE, N. M. Amblyomma cooperi (Acari: Ixodidae) parasitando humano em área de foco de febre maculosa, São Paulo - Brasil. Acta Parasitology Portuguesa, Lisboa, v. 4, p. 154, 1997. Suplemento 1,

FIGUEIREDO, M. A. P.; SANTOS, A. C. G.; GUERRA, R. M. S. N. C. Ectoparasitos de animais silvestres no Maranhão. Pesquisa Veterinária Brasileira, Seropédica, v. 30, n. 11, p. 988-990, nov. 2010.

GRAHAM, O. H.; HOURRIGAN, J. L. Erradication programs for the arthopod parasite of livestock. Journal of Medical Entomology, Lanhan, v. 13, n. 1, p. 629-659, 1977.

GUGLIELMONE, A. A.; ESTRADA-PEÑA, A.; MANGOLD, A. J.; BARROS-BATTESTI, D. M.; LABRUNA, M. B.; MARTINS, J. R.; VENZAL, J. M.; ARZUA, M.; KEIRANS, J. E. Amblyomma aureolatum (Pallas, 1772) and Amblyomma ovale Koch, 1844 (Acari:
Ixodidae): hosts, distribution and $16 \mathrm{~S}$ rDNA sequences. Veterinary Parasitology, Amsterdam, v. 113, n. 3-4, p. 273-288, maio 2003.

GUIMARÃES， J. H.; TUCCI， E. C.; BARROSBATTESTI, D. M. Ectoparasitos de importância veterinária. São Paulo: Plêiade/FAPESP, 2001. 218 p.

ITO, F. H.; VASCONCELLOS, S. A.; BERNARDI, F.; NASCIMENTO, A. A.; LABRUNA, M. B.; ARANTES, I. G. Evidência sorológica de brucelose e leptospirose e parasitismo por ixodídeos em animais silvestres do pantanal Sul-Mato-Grossense. ARS Veterinária, Jaboticabal, v. 14, n. 3, p. 302-310, 1998.

LABRUNA, M. B.; PAULA, C. D. de; LIMA, T. F.; SANA, D. A. Ticks (Acari: Ixodidae) on wild animals from the Porto-Primavera Hydroelectric Power Station Area, Brazil. Memórias do Instituto Oswaldo Cruz, Rio de Janeiro, v. 97, n. 8, p. 1133-1136, dez. 2002.

LABRUNA, M. B.; JORGE, R. S.; SANA, D. A.; JÁCOMO, A. T.; KASHIVAKURA, C. K.; FURTADO, M. M.; FERRO, C.; PEREZ, S. A.; SILVEIRA, L.; SANTOS, T. S.; MARQUES, S. R.; MORATO, R. G.; NAVA, A.; ADANIA, C. H.; TEIXEIRA, R. H.; GOMES, A. A.; CONFORTI, V. A.; AZEVEDO, F. C.; PRADA, C. S.; SILVA, J. C.; BATISTA, A. F.; MARVULO, M. F.; MORATO, R. L.; ALHO, C. J.; PINTER, A.; FERREIRA, P. M.; FERREIRA, F.; BARROS-BATTESTI, D. M. Ticks (Acari: Ixodida) on wild carnivores in Brazil. Experimental and Applied Acarology, Amsterdam, v. 36, n. 1-2, p. 149-163, 2005.

LAVINA, M. S.; SOUZA, A. P.; SOUZA, J. C.; BELlATO, V.; SARTOR, A. A.; MOURA, A. B. Ocorrência de Amblyomma aureolatum (Pallas, 1772) e A. ovale (Kock, 1844) (Acari: Ixodidae) parasitando Alouatta clamitans Cabrera, 1940 (Primates: Atelidae) na região Norte do estado de Santa Catarina. Arquivo Brasileiro de Medicina Veterinária e Zootecnia, Belo Horizonte, v. 63, n. 1, p. 266-269, fev. 2011.

LUZ, H. B.; FACCINI, J. L. H. Parasitismo por carrapatos em anuros no Brasil. Revisão. Veterinária e Zootecnia, Botucatu, v. 20, p. 100-111, 2013. Edição Comemorativa.

MARTINS, J. R. S.; RECK JÚNIOR, J.; DOYLE, R. L.; DA CRUZ, N. L. N.; VIEIRA, A. W. de M.; SOUZA, U. A. Amblyomma aureolatum (Acari: Ixodidae) parasitizing margay (Leopardus wiedii) in Rio Grande do Sul. Revista Brasileira de Parasitologia Veterinária, Jaboticabal, v. 19, n. 3, p. 189-191, jul./set. 2010.

MASSARD, C. L.; FONSECA, A. H. Carrapatos e doenças transmitidas comuns ao homem e aos animais. A Hora Veterinária, Porto Alegre, v. 135, n. 1, p. 15-23, 2004. 
MONTEIRO, M. A. Caracterização climática do estado de Santa Catarina: uma abordagem dos principais sistemas atmosféricos que atuam durante o ano. Geosul, Florianópolis, v. 16, n. 31, p. 69-78, jan./jun. 2001. Disponível em: <http://www.dca.iag.usp.br/www/ material/ritaynoue/fisica $\% 20 \mathrm{da} \% 20$ tera $\% 20 \mathrm{e} \% 20 \mathrm{do} \%$ 20universo/2013>. Acesso em: 12 mar. 2015.

PEREIRA, A. A. Aspectos da ecologia de Boophilus microplus (CANESTRINI, 1887) (ACARINA: IXODIDAE) no município de Franca, nordeste de São Paulo. 2008. Tese (Doutorado em Medicina Veterinária, Área da Patologia Animal) - Universidade Estadual Paulista. Faculdade de Ciências Agrárias e Veterinárias, Jaboticabal.

QUADROS, R. M.; LAVINA, M. S.; MARQUES, S. M. T.; FRANÇA, M.; VERONEZI, W. R.; CARNEIRO JÚNIOR, J. A. Amblyomma cajennense and Amblyomma dubitatum in capybaras run over on high ways in Santa Catarina State, Brazil. Neotropical Biology and Conservation, São Leopoldo, v. 8, n. 3, p. 176-179, 2013.

ROBINSON, L. E. Ticks. A monograph of the Ixodoidea. Part IV. The Genus Amblyomma. London: Cambridge University, 1926. 302 p.

RODRIGUES, A. F. S. F.; DAEMON, E. Ixodídeos e sifonápteros em Cerdocyon thous L. (Carnivora, Canidae) procedentes da Zona da Mata Mineira, Brasil. Arquivos do Instituto Biológico, São Paulo, v. 71, n. 3, p. 371-372, jul./set. 2004.
SILVEIRA, J. A. G.; OLIVEIRA, P. A.; CURI, N. H. A.; BARATA, R. S. L.; CHIARELLO, A. G.; RIBEIRO, M. F. B. Ocorrência de Amblyomma longirostre (Koch, 1844) em Chaetomys subspinosus (Olfers, 1818) oriundos da Mata Atlântica. Arquivo Brasileiro de Medicina Veterinária e Zootecnia, Belo Horizonte, v. 60, n. 3, p. 772-774, 2008.

SINKOC, A. L.; BRUM, J. G. W. Ocorrência de Amblyomma fuscum NEUMANN, 1899 e Amblyomma humerale KOCH, 1844 (Acari: Ixodidae) em Bufo arenalis no estado de São Paulo, Brasil. Ciência Rural, Santa Maria, v. 27, n. 2, p. 339-340, 1997.

SZABÓ, M. P. J.; LABRUNA, M. B.; PEREIRA, M. C.; DUARTE, J. M. Ticks (Acari: Ixodidae) on wild marshdeer (Blastocerus dichotomus) from Southeast Brazil: infestations before and after habitat loss. Journal of Medical Entomology, Honolulu, v. 40, n. 3, p. 268-274, maio 2003.

TEIXEIRA, R. H. F.; FERREIRA, I.; AMORIM, M.; GAZETA, G. S.; SERRA-FREIRE, N. M. Carrapatos em aves selvagens no Zoológico de Sorocaba, São Paulo, Brasil. Arquivo Brasileiro de Medicina Veterinária e Zootecnia, Belo Horizonte, v. 60, n. 5, p. 1277-1280, 2008.

WILLIAMS, E. S.; YUILL, T.; ARTOIS, M.; FISHER, J.; HAIGH, S. A. Emerging infectious disease in wildlife. Revista Sci Tech OIE, Berlin, v. 21, n. 1, p. 139-157, 2002. 
